\title{
Physicians: It's in Your Court Now
}

\author{
Reprinted from the Canadian Medical Association Journal 173(3): $275-77$ by permission of the \\ publisher. @ 2005 CMA Media Inc.
}

\section{Steven Lewis}

The Supreme Court decision of June 9, 2005 clarifies the political choice facing organized medicine in Canada. ${ }^{1}$ Many of Canada's doctors are strong and eloquent supporters of single-tier health care. Many are not, and never have been. A mere decade ago, at the CMA's annual General Council meeting, a motion declaring that citizens "must have the right to choose regulated private insurance for all medical services" fell on a vote of 88 to $68 .{ }^{2}$ Focus groups conducted by the CMA in 1996 revealed a wide chasm between the strong public support for public health care and the then $78 \%$ of physicians who believed stronger privatesector participation in health care was either very or somewhat acceptable. ${ }^{3}$ And, of course, organized medicine was heatedly opposed to the introduction of medicare in Saskatchewan in 1962. More often than not, doctors' organizations have strongly opposed measures that they have subsequently embraced. In this they are no different from any other privileged group - whatever their virtues, attunement to the will of the demos is not among them.

The profession's support for singletier health care has always been provisional, and it has been largely silent - one must infer approvingly so - on the growth of for-profit clinics. Some physicians have contracted out to the public system, others have plied their trade on both sides of the street and a few have abandoned medicare altogether. Until June 9, the debates among doctors were not central to the future of the system. Proponents of a private and parallel option had to chip away at medicare's edges, abetted by a federal government that has been castigated by the Auditor General for refusing to enforce the Canada Health Act. Now "private and parallel" has the high court's blessing, with a new twist: the legal buying and selling of insurance for medically necessary services. The court has tasered medicare; the question is now whether the system is temporarily stunned, or mortally wounded.

CMA President Albert Schumacher declared the Supreme Court judgment "a stinging indictment of the failure of 
governments to respond to the mountains of studies that show we need real action on our health care system." That we need real action on our health care system is incontestable. That government should be the exclusive or even principal target of indictment is the question on the table. The evidence suggests we should look elsewhere.

Governments fund health care and establish its general legislative and regulatory framework. Beyond that, the system is largely in the hands of physicians, who make the day-to-day decisions, prioritize patients, prescribe drugs, admit patients to and discharge them from hospital, order tests and carry out innumerable interventions with a remarkable degree of autonomy. They are not held accountable in any meaningful way for performance. They are indifferent, apparently, to the clinical practice guidelines produced by their own colleagues. There are huge variations in their practices that go unchecked, despite the obvious implications for quality and access. ${ }^{4-7}$

The "real action" needed on our health care system includes primary health care reform, a more rational division of labour, quality improvement and a remedy for inequities in pay scales that overvalue day-surgery assembly lines and undervalue geriatricians and rheumatologists. The call for these reforms has come largely from governments, and it has been thwarted or delayed not by governments but by doctors. ${ }^{8}$ Both Romanow and Kirby noted the glacial advance of primary care reform. It is medical associations, not governments, that allocate incomes among specialties. Nurse practitioners, pharmacists and therapists are anxious to expand their scope of practice and to use their expertise fully. Try to find a government that disagrees. Try to find a medical association fully on board.

According to organized medicine, system failings are always someone else's fault. Somehow Mr. Zeliotis' hip surgery delay was caused by the nature and stinginess of the singlepayer system. Nothing, apparently, is attributable to physicians retaining control over their individual wait lists and refusing to standardize criteria for assessing and prioritizing patients. ${ }^{9}$ The failure to look for doctors with shorter wait times, to share responsibility for fairness and to participate in the kinds of process improvements that by 2003 got $88 \%$ of UK citizens into primary care within 48 hours of picking up the phone ${ }^{10}$ is - government's. If it's government's fault, it's because government didn't follow Whitehall's lead and just say no to chaos.

Given its anarchic characteristics, it is bordering on miraculous that the system by and large serves most people well most of the time. The median wait time for cardiac surgery in Manitoba is 23 days. ${ }^{11}$ Median wait times in British Columbia are well under three months for every surgical category except for corneal transplants (17 weeks), hip replacements (22 weeks) and knee replacements ( 28 weeks). ${ }^{12}$ In Saskatchewan in 2004, 82\% of surgeries were completed within six months, but $5 \%$ had wait times longer than 18 months. ${ }^{13}$ And here is where the problem comes home to roost: if even 
as few as half of the $5 \%$ were waiting involuntarily, great harm was done.

Who is responsible? Governments don't manage the wait lists.

Governments are not responsible for following up, or not, with patients waiting for procedures. Governments do not decide that patient A will get served in two months while patient $B$, with identical needs, will wait 20 months. Doctors do. The Canadian long waits are not a capacity problem: simple arithmetic demonstrates that no one has to wait 18 months in a system where 4 out of 5 (or more) patients wait well under six months. But until recently the only response of organized medicine to these long waits was to cry poverty and enlist the public in government bashing. One would have thought the Hippocratic oath would have diverted some of this energy toward looking after the long-suffering. It does not take a cynic to observe that the long queues admirably served the purpose of extracting more money for health care - both public and private. And they also provided the pretext for Chaoulli, and here we are.

The history of medicare is a clash between the state's goals of equity, order and efficiency with medicine's goals of autonomy, growth and control. Society has made enormous concessions to organized medicine, such as the right of doctors to set up practice anywhere, the right to remain independent contractors rather than full partners in a complex system, freedom from the measurement, scrutiny and accountability of US-style managed care, and pay scales that vastly exceed those extant in the European systems the court and medicare's critics selectively admire from afar. It has also encouraged governments to increase public spending by an astonishing $60 \%$ in the past eight years, an ongoing mea culpa for the four-year period in the last 35 when spending modestly declined. All the public expects in return is a shared commitment to single-tier equity, a willingness to participate in reforms and decent performance. Apparently this has been too much to ask.

Now, thanks to the Supreme Court, the legal underpinnings of the system have been dealt a blow, and the choices are starker for doctors. They can now openly abandon the public system and get in on the ground level of an emerging private insurance system catering to people with money. They can market the virtues of commodified medicine and concentrate on the sexy diagnostics and high-volume procedures under the guise of enhancing Canadians' Charter rights. No more unlucrative sessions with the complex geriatric case. No more dealing with intractable chronic diseases. No more unrewarding encounters with the underclass. It's an easy and pleasant $\$ 275,000$ a year for family doctors at a clinic that bundles core services with the extras, charging $\$ 1,700$ up front and $\$ 2,300$ annually. ${ }^{14}$ No doubt surgeons in the orthopedic and cataract centres can easily double and triple that income.

The Supreme Court has raised the stakes, and the public needs to know where official medicine stands. Will it accelerate public-system reforms, improve its performance and effectively 
preempt the market for private insurance? Or will it decant more care to the private sector, which, according to recent evidence from Australia's hybrid system, increases public sector wait times? ${ }^{15}$ Will it promote a fair income distribution so that graduating doctors no longer leave family medicine and geriatrics residencies unfilled while they flock to dermatology and orthopedics? Will it propose and participate in comprehensive wait-list management systems, like Saskatchewan's, to ensure that no patient's health is endangered by unmonitored waits and that those with greater needs get served first? Will it leap to the fore of the quality revolution, or continue to provide an endless source of material for the small-areavariation research industry? 16

\section{Now, thanks to the Supreme Court, the legal underpinnings of the system have been dealt a blow, and the choices are starker for doctors.}

Perhaps, in its testily divided decision, the court has done the country a favour. We have not had a national, focused debate on where to draw the line on two-tier health care for decades, resorting to fictions about medically unnecessary services and ignoring the evidence under our very noses - most recently that for-profit long-term care facilities provide significantly less direct and support care to residents than their nonprofit counterparts. ${ }^{17}$ Nor have we carefully and conclusively debated Tommy Douglas's unrealized vision of a genuinely balanced continuum of care. Physicians have fought long and successfully to remain at arm's length from the system. You wouldn't get on a plane built by engineers who decided independently what parts to make and whether and how to fit them together. Why would anyone expect excellence from a health care system that is largely ungoverned and where mistakes and overuse trigger an avalanche of funding and income while prudent, efficient practice has the bracing effect of lowering one's income?

This is not a time for hysteria or fear-mongering, but for self-examination, reflection and choice. How governments respond to the challenge is of course vitally important, and the political exchanges promise to be lively. But citizens and governments delude themselves if they imagine that a public system can succeed without a medical profession that is widely and officially committed to its values and more often than not promotes rather than resists constructive change.

For too long the rule of the game has been to spend more or lose physician support. We've spent more - a lot more - and the return on investment has been low. Canada is a country governed by elites. Will the medical profession rise to the challenge of creating a new and improved medicare, or will it, like so many elites, talk about the public interest but act in the interests of the few? 
Steven Lewis is with Access Consulting Ltd., in Saskatoon, SK., and the Centre for Health and Policy Studies, University of Calgary, Calgary, AB.

Correspondence to: Steven Lewis, Access Consulting Ltd., 211-4th Ave. S., Saskatoon SK S7K 1N1; fax 306-343-1071; steven.lewis@shaw.ca.

\section{References}

1. Chaoulliv. Quebec (Attorney General). 2005 SCC 35.

2. Sullivan P. Private health care dominates meeting as General Council calls for national debate. CMAJ 1995;153(6):801-3.

3. Sullivan P. Focus groups confirm that MDs, public differ on role of private health care. CMAJ 1996;154(8):1247-9.

4. Kennedy J, Quan H, Ghali WA, Feasby TE. Variations in rates of appropriate and inappropriate carotid endarterectomy for stroke prevention in 4 Canadian provinces. CMAJ 2004;171(5):4559.

5. Jaglal SB, Carroll J, Hawker G, McIsaac WJ, Jaakkimainen L, Cadarette SM, et al. How are family physicians managing osteoporosis? Qualitative study of their experiences and educational needs. Can Fam Physician 2003;49:462-8.

6. Brownell M. Tonsillectomy rates for Manitoba children: temporal and spatial variations. Healthc Manage Forum 2002;Suppl:21-6.

7. Katz A, DeCoster C, Bogdanovic B, Soodeen RA, Chateau D. Using administrative data to develop indicators of quality in family practice. Winnipeg: Manitoba Centre for Health Policy; 2004. Available: www.umanitoba.ca/centres /mchp/reports/pdfs/quality_wo.pdf (accessed 2005 Jun 20).

8. Medical Reform Group. Nearsighted physicians reject deal with government [media release]. Toronto: The Group; 2004 Nov 21. Available: www.hwcn.org /link/mrg/press.release. html\#Nearsighted_Physicians_Reject_Deal_With (accessed 2005 Jun 20).

9. Sanmartin C, Shortt SED, Barer ML, Sheps S, Lewis S, McDonald PW. Waiting for medical services in Canada: lots of heat, but little light. CMAJ 2000;162(9):1305-10.

10. Department of Health. Achieving shorter waits: the PPF promises shorter waiting times across the service. London (UK): The Department; 2005. Available: www.dh.gov.uk/ PolicyAndGuidance/PatientChoice/Waiting Booking Choice/WaitingBookingChoiceArticle/
fs/en?CONTENT_ID=4066038\&chk $=$ ZurIX5 (accessed 2005 Jun 20).

11. Winnipeg Regional Health Authority. Health services wait time information: cardiac surgery. Winnipeg: Manitoba Health. Available: www.gov. mb.ca/health/waitlist/cardiac.html (accessed 2005 Jun 20).

12. Median wait times and wait lists. Victoria: Government of British Columbia; 2005 Mar 31. Available: www.healthservices.gov.bc.ca/cpa/ mediasite/waittime/median.html (revised 2005 May 17, accessed 2005 Jun 20).

13. Wait time information. Regina: Saskatchewan Surgical Care Network. Available: www.sasksurgery.ca/wait-list-info.html (accessed 2005 Jun 20).

14. Copeman D. Interview with Don Copeman, Copeman Health Centre, Vancouver. Interviewed by Barbara Budd and Mary Lou Finlay, As It Happens [radio program]; 2005 Jun 1. Produced by the Canadian Broadcasting Corporation, Toronto. Available: www.cbc.ca/insite/AS_IT_ HAPPENS_TORONTO/2005/6/1.html (accessed 2005 Jun 20).

15. Duckett SJ. Private care and public waiting. Aust Health Rev 2005;29:87-93.

16. Tu JV, Pinfold SP, McColgan P, Laupacis A. April 2005. Access to health services in Ontario: ICES Atlas. Toronto: Institute for Clinical Evaluative Sciences; 2005. Available: www.ices.on.ca/webpage.cfm?site_id=1\&org $\mathrm{id}=67 \&$ morg_id=0\&gsec_id=0\&item_ $\mathrm{id}=2862 \&$ type $=$ atlas $($ accessed 2005 Jun 20).

17. McGregor MJ, Cohen M, McGrail K, Broemeling AM, Adler RN, Schulzer M, et al. Staffing levels in not-for-profit and for-profit long-term care facilities: Does type of ownership matter? CMAJ 2005;172(5):645-9. 